\title{
Subglacial processes on an Antarctic ice stream bed. 1: Sediment transport and bedform genesis inferred from marine geophysical data
}

\author{
STEPHEN J. LIVINGSTONE, ${ }^{1}$ CHRIS R. STOKES, ${ }^{2}$ COLM Ó COFAIGH, ${ }^{2}$ \\ CLAUS-DIETER HILLENBRAND, ${ }^{3}$ ANDREAS VIELI, ${ }^{2,4}$ STEWART S. R. JAMIESON, ${ }^{2}$ \\ MATTEO SPAGNOLO, ${ }^{5}$ JULIAN A. DOWDESWELL ${ }^{6}$ \\ ${ }^{1}$ Department of Geography, University of Sheffield, Sheffield, UK \\ ${ }^{2}$ Department of Geography, Durham University, Durham, UK \\ ${ }^{3}$ British Antarctic Survey, Cambridge, UK \\ ${ }^{4}$ Department of Geography, University of Zurich, Winterthurerstr, Zurich, Switzerland \\ ${ }^{5}$ Department of Geography and Environment, School of Geosciences, University of Aberdeen, Aberdeen, UK \\ ${ }^{6}$ Scott Polar Research Institute, University of Cambridge, Cambridge, UK \\ Correspondence: Stephen J. Livingstone <s.j.livingstone@sheffield.ac.uk>
}

\begin{abstract}
The spatial pattern and morphometry of bedforms and their relationship to sediment thickness have been analysed in the Marguerite Bay Palaeo-ice stream Trough, western Antarctic Peninsula. Over 17000 glacial landforms were measured from geophysical datasets, and sediment thickness maps were generated from acoustic sub-bottom profiler data. These analyses reveal a complex bedform pattern characterised by considerable spatial diversity, influenced heavily by the underlying substrate. The variability in length and density of mega-scale lineations indicates an evolving bedform signature, whereby landforms are preserved at different stages of maturity. Lineation generation and attenuation is associated with regions of thick, soft till where deformation was likely to be the greatest. The distribution of soft till and the localised extent of grounding-zone wedges (GZWs) indicate a dynamic sedimentary system characterised by considerable spatio-temporal variability in sediment erosion, transport and deposition. Formation of GZWs on the outer shelf of Marguerite Trough, within the error range of the radiocarbon dates, requires large sediment fluxes (upwards of $1000 \mathrm{~m}^{3} \mathrm{a}^{-1}$ (m grounding line width) ${ }^{-1}$ ), and a $>1 \mathrm{~m}$ thick mobile till layer, or rapid basal sliding velocities (upwards of $6 \mathrm{~km} \mathrm{a}^{-1}$ ).
\end{abstract}

KEYWORDS: glacial lineations, grounding-zone wedges, ice stream, mega-scale, subglacial bedforms, till

\section{INTRODUCTION}

The drainage of continental ice sheets is organised into a series of tributaries that feed rapidly-flowing outlet glaciers known as ice streams (Bamber and others, 2000). Due to their rapid flow, ice streams account for $50-90 \%$ of ice discharge from modern ice sheets and recent observations of their thinning and acceleration indicate that their contribution to sea level rise has increased over the past few decades (Pritchard and others, 2009; Moon and others, 2012). The mechanisms driving these changes are likely to involve both atmospheric and oceanic warming, but evolving conditions on the beds of ice streams also play a crucial role in modulating their behaviour (e.g. Engelhardt and Kamb, 1997; Anandakrishnan and others, 1998). These bed conditions include characteristics such as topography, geothermal and frictional heat, subglacial water and sedimentary/geomorphological processes; all of which evolve through time to enhance or inhibit rapid ice stream flow (Alley and others, 1986; Tulaczyk and others, 2000a, b; Parizek and others, 2002; Schoof, 2002; Stokes and others, 2007). Direct access to, and observations of the subglacial environment of present day ice streams in Greenland and Antarctica are challenging. Technological advances have permitted pioneering borehole (e.g. Engelhardt and Kamb, 1997) and geophysical investigations (e.g. Smith and others, 2007; King and others, 2009), but boreholes are restricted to relatively small spatial and temporal 'windows' of the ice stream bed. An alternative approach is to seek out locations where ice streams formerly operated and use the well-preserved bed imprint to investigate subglacial processes, i.e. in positions distal to modern ice stream termini (e.g. Jakobsson and others, 2012) or from the beds of palaeo-ice sheets (e.g. Stokes and Clark, 2001). However, relatively few studies have undertaken comprehensive mapping and detailed quantitative/statistical analysis of palaeo-ice stream beds (e.g. Dowdeswell and others, 2004a; Livingstone and others, 2013; Stokes and others, 2013; Spagnolo and others, 2014; Klages and others, 2015), which are required to fully characterise their basal environment over large spatial scales.

Using a recent map presented by Livingstone and others (2013), our aim is to analyse the spatial pattern and morphometry of ice stream bedforms and their relation to till properties and thickness on the former Marguerite Bay ice stream (MBIS), western Antarctic Peninsula, to understand ice stream retreat patterns, sedimentary processes and bedform genesis. The results are presented in two papers: in the first paper we analyse 17000 individual landforms (Livingstone and others, 2013) and explore the implications with respect to sediment transport and the formation of 
subglacial bedforms along the MBIS trough. In the second paper (Jamieson and others, 2016) we integrate these data with a two-dimensional (2-D) numerical flow-line model to make a preliminary exploration of the links between the observed geomorphology and modelled ice stream dynamics.

\section{STUDY AREA AND PREVIOUS WORK}

On the west side of the Antarctic Peninsula a $50-80 \mathrm{~km}$ wide bathymetric trough (Marguerite Trough) extends from inner Marguerite Bay at the mouth of George VI Sound for 370 $\mathrm{km}$ to the continental shelf edge (Fig. 1). Water depths in the trough shallow from $1600 \mathrm{~m}$ on the inner shelf to $500 \mathrm{~m}$ at the shelf edge, whereas on the adjoining banks they range from 400 to $500 \mathrm{~m}$ (Fig. 1). Seismic data reveal that the substrate of Marguerite Trough changes from sedimentary strata on the outer shelf to indurated sedimentary bedrock and crystalline basement on the middle and inner shelf (Bart and Anderson, 1995; Larter and others, 1997; Fig. 5.20 in Anderson, 1999). Presently, the George VI Ice Shelf covers parts of the inner bay in George VI Sound (Fig. 1).

There have been several marine geophysical and geological studies of the glacial geomorphology and geology of Marguerite Bay and Marguerite Trough (e.g. Kennedy and Anderson, 1989; Pope and Anderson, 1992; Ó Cofaigh and others, 2002, 2005, 2007, 2008; Dowdeswell and others, 2004a, b; Heroy and Anderson, 2005; Anderson and Oakes-Fretwell, 2008; Livingstone and others, 2013). Using swath bathymetric records of the sea floor morphology along the trough, Ó Cofaigh and others (2002) showed an along-flow progression in bedform evolution with icemoulded bedrock, drumlins and subglacial meltwater channels formed predominantly in bedrock in the inner bay, which transition to classical drumlins, highly attenuated drumlins and glacial lineations on the mid-shelf, and then to mega-scale glacial lineations (MSGLs) up to $20 \mathrm{~km}$ in length and formed in sediments across the outer shelf. Thus, bedforms are present over both the crystalline substrate of the inner and mid-shelf, and the sedimentary substrate of the outer shelf. The subglacial bedforms have a consistent orientation, showing ice flow along the trough, and were interpreted to record former streaming flow draining through Marguerite Trough to the shelf edge during the last glaciation (Ó Cofaigh and others, 2002).

Topographic Parametric Sonar (TOPAS) acoustic subbottom profiler and reflection seismic data from along the trough show a rough and irregular sea floor in the inner to mid-shelf parts of the trough, which reflects the crystalline bedrock substrate (Bart and Anderson, 1995; Ó Cofaigh and others, 2005). However, on the outer shelf, the TOPAS records show that the MSGLs are formed in the upper part of an acoustically transparent sediment unit which sits over a strong basal reflector (Dowdeswell and others, 2004a; Ó Cofaigh and others, 2005). This acoustic facies is thickest along the centre of the trough, but was not found on the adjoining banks. Cores from this acoustic facies show that it comprises a soft (shear strengths of $0-20 \mathrm{kPa}$ ), porous (35-45\%), massive, matrix-supported diamicton interpreted as a subglacial till (Dowdeswell and others, 2004a; Ó Cofaigh and others, 2005). Detailed analysis of the soft till showed that it is a 'hybrid' formed by a combination of subglacial sediment deformation and lodgement with individual shear zones of $0.1-0.9 \mathrm{~m}$ in thickness (Ó Cofaigh and others, 2007, 2014).

The retreat history of the MBIS is constrained by radiocarbon dates from marine sediment cores (Fig. 1; Harden and others, 1992; Pope and Anderson, 1992; Ó Cofaigh and others, 2005, 2014; Heroy and Anderson, 2007; Kilfeather and others, 2011). Compared with other Antarctic palaeoice streams, the radiocarbon chronology for the MBIS retreat is comparatively robust because the majority of marine dates were obtained from calcareous (micro-)fossils and down-core age reversals were not observed. Following the approach of Heroy and Anderson (2007) and using only the most reliable ages (see Fig. 1), the chronology suggests a non-linear pattern of ice stream retreat characterised by rapid deglaciation of $140 \mathrm{~km}$ of the outer shelf $\sim 14$ cal. ka BP, followed by a slower phase of retreat through the mid-shelf that was associated with the break-up of an ice shelf and, thereafter, rapid retreat to the inner shelf at 9 cal. ka BP (Fig. 1) (Heroy and Anderson, 2007; Kilfeather and others, 2011; Jamieson and others, 2012). The mean grounding-line retreat rate of MBIS was $\sim 80 \mathrm{~m} \mathrm{a}^{-1}$, although during the two periods of rapid retreat across the outer-mid shelf, the rates of recession were much greater, occurring within the error range of the radiocarbon dates (Livingstone and others, 2012).

\section{DATA AND METHODS}

\subsection{Geophysical and geological data}

Marine geophysical and geological data for this study were collected on cruises JR59, JR71 and JR157 of the RRS lames Clark Ross (JCR) and NBP0201 of the RV/IB Nathaniel B. Palmer (NBP) (Fig. 1). Swath bathymetry data were obtained using Kongsberg EM120 (JCR) and hullmounted SeaBeam 2100 (NBP) multibeam echo-sounders and gridded at $\sim 15 \mathrm{~m} \times 45 \mathrm{~m}$ in MB-System (Caress and Chayes, 2003). A geomorphological map of the Marguerite Bay palaeo-ice stream is published in Livingstone and others (2013) and these mapped features (Fig. 2) form the basis for the analysis presented here.

Shallow acoustic seismic data were obtained on JCR cruises JR59 and JR71 using a Kongsberg TOPAS subbottom profiler. Sediment thicknesses were calculated assuming a sound velocity of $1500 \mathrm{~m} \mathrm{~s}^{-1}$ (cf. Dowdeswell and others, 2004a). We derived thickness maps of soft till and postglacial sediments (including deglacial sediments) at $200 \mathrm{~m}$ horizontal resolution using an ordinary Kriging technique with a spherical semivariogram model. Where an acoustic sub-bottom reflector depicting the boundary between an upper soft and a lower stiff till layer was not observed, 'no data' values were assigned as this could indicate an absence of soft till or a layer of soft till that was so thick that the TOPAS profiler was unable to penetrate it fully (cf. Reinardy and others, 2011a). The age constraints used for calculating sediment fluxes are those highlighted in bold in Figure 1 (the figure caption provides references for radiocarbon dates).

\subsection{MSGL measurements}

In this paper, we follow the approach of Livingstone and others (2013) and use the term 'mega-scale glacial lineations' for all linear features that do not clearly initiate from or are 


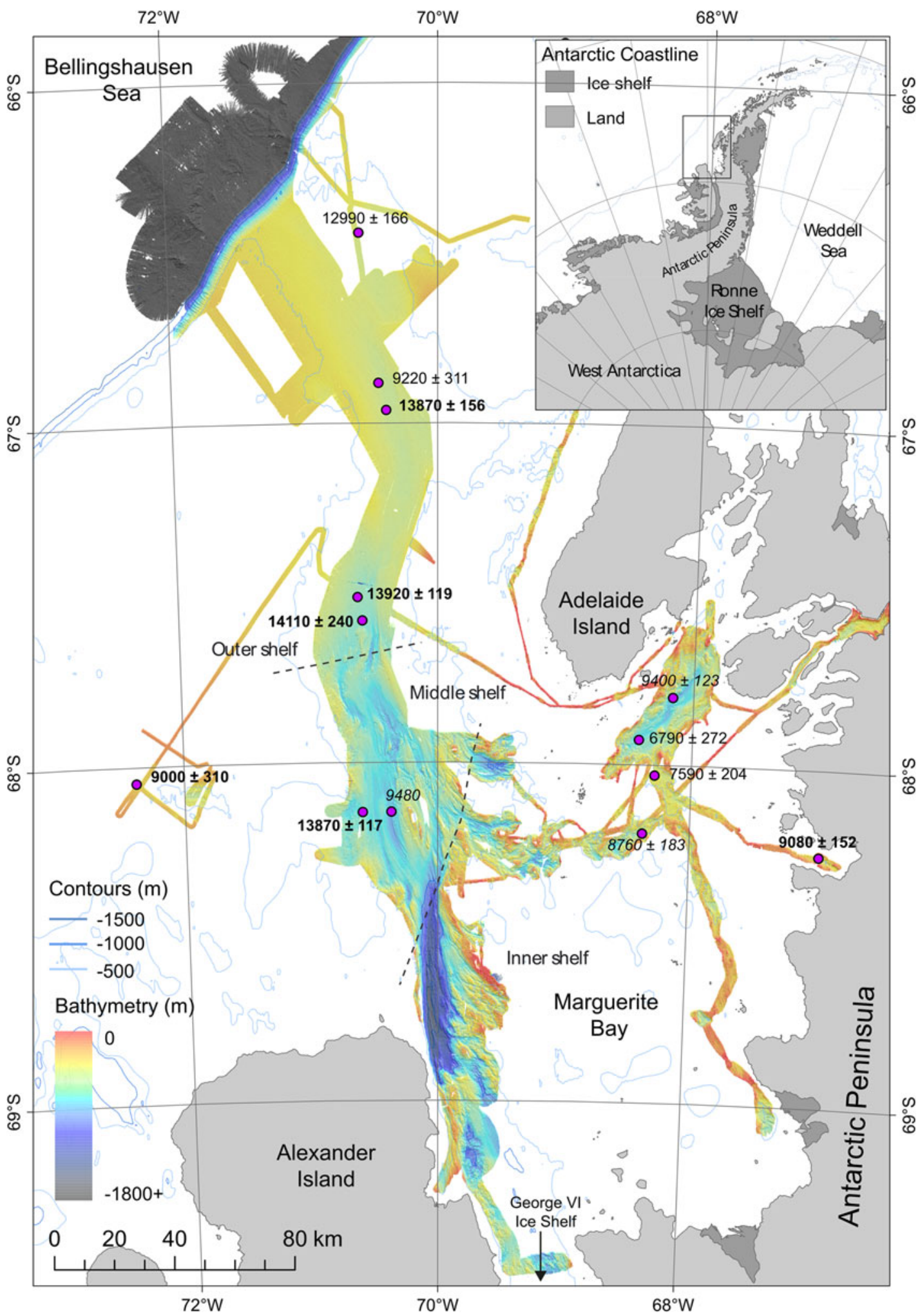

Fig. 1. Location map showing the general bathymetry of the continental shelf in the vicinity of Marguerite Trough and locations of cores (after Livingstone and others, 2013). The swath bathymetry (colour scale) is a compilation of research cruises JR59, JR71, JR157 and NBP0201. The dashed dark grey lines define the outer, mid and inner shelf regions as discussed in Section 4.1. They were delimited on the basis of their bed physiography using the multibeam and TOPAS data as sediment-floored, mixed bedrock-sediment and predominantly bedrock, respectively. The inner shelf encompasses Marguerite Bay. Deglaciation ages from the cores (Harden and others, 1992; Pope and Anderson, 1992; Heroy and Anderson, 2007; Kilfeather and others, 2011) are displayed with 1 sigma error and the dates in bold refer to the most reliable core dates (i.e. those that sampled the contact marking the onset of glaciomarine sedimentation, were derived from calcareous micro-fossils and not affected by iceberg turbation (see Heroy and Anderson, 2007)). Ages derived from cores that sampled the transitional glaciomarine facies, but did not penetrate into subglacial till are shown in italics as they record a minimum age for ice retreat. We used only the most reliable ages highlighted in bold to reconstruct the chronology of grounding-line retreat. Note that the dates suggest rapid retreat from the outermid shelf at $\sim 14$ cal. ka BP, followed by a period of slower retreat towards the inner shelf and then another phase of rapid retreat across the inner shelf at $\sim 9$ cal. ka BP. 


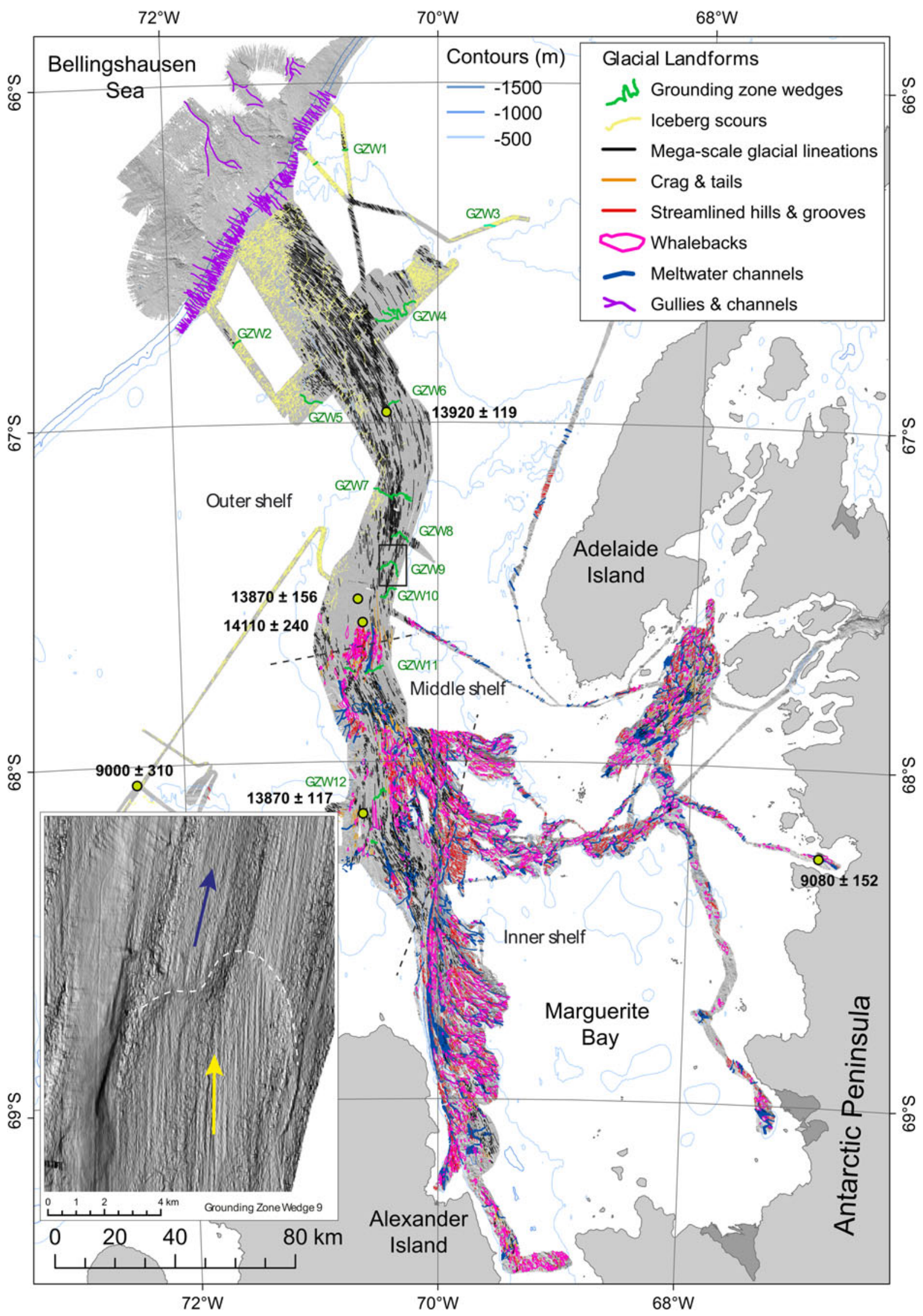

Fig. 2. Glacial geomorphological map of Marguerite Trough (from Livingstone and others, 2013). Reliable deglacial core ages are displayed with 1 sigma error (yellow dot and bold text). Note the variety of landforms on the middle and inner shelf, which are floored by sediment and bedrock. In particular, meltwater channels are predominantly formed in bedrock, with no channels identified on the outer shelf. The outer shelf is dominated by MSGLs, GZWs and iceberg scours. Inset box is a close-up of GZW9 illustrating the MSGLs on the gentle back-slope of the GZW and downstream of its crest, thereby highlighting a subtle shift in MSGL orientation (arrows) 
Table 1. Measured length $(L)$, width $(W)$ and crest height $(H)$ and calculated volume $(V)$ of GZWs $7-10$ (see Fig. 2 for locations). The GZW volume was calculated using the following equation: $V=(L \times W \times H) / 2$. The time of grounding line stagnation at each of the GZWs was estimated from Eqn (1) using a range of typical 2-D sediment fluxes $\left(\mathrm{m}^{3} \mathrm{a}^{-1} \mathrm{~m}^{-1}\right.$ of grounding line width) (see references in main text). The 3-D sediment flux was calculated by multiplying the 2-D sediment flux by the GZW width

Grounding line stagnation for a range of typical sediment fluxes

\begin{tabular}{|c|c|c|c|c|c|c|c|c|c|c|}
\hline \multirow{3}{*}{ GZW } & \multirow{3}{*}{$\begin{array}{l}\text { Length } \\
\text { m }\end{array}$} & \multirow{3}{*}{$\begin{array}{l}\text { Width } \\
\text { m }\end{array}$} & \multirow{3}{*}{$\begin{array}{c}\text { Crest } \\
\text { height } \\
\text { m }\end{array}$} & \multirow{3}{*}{$\begin{array}{c}\text { Volume } \\
\mathrm{m}^{3}\end{array}$} & \multicolumn{2}{|c|}{$100 \mathrm{~m}^{3} \mathrm{~m}^{-1} \mathrm{a}^{-1}$} & \multicolumn{2}{|c|}{$1000 \mathrm{~m}^{3} \mathrm{~m}^{-1} \mathrm{a}^{-1}$} & \multicolumn{2}{|c|}{$8000 \mathrm{~m}^{3} \mathrm{~m}^{-1} \mathrm{a}^{-1}$} \\
\hline & & & & & 3D flux & Duration & 3D flux & Duration & 3D flux & Duration \\
\hline & & & & & $m^{3} a^{-1}$ & a & $m^{3} a^{-1}$ & a & $m^{3} a^{-1}$ & a \\
\hline 10 & 14000 & 13000 & 22 & $2.002 \times 10^{9}$ & $1.3 \times 10^{6}$ & 1540 & $1.3 \times 10^{7}$ & 154 & $1.04 \times 10^{8}$ & 19.5 \\
\hline 9 & 9500 & 5600 & 30 & $7.980 \times 10^{8}$ & $9.5 \times 10^{5}$ & 840 & $9.5 \times 10^{6}$ & 84 & $7.6 \times 10^{7}$ & 10.5 \\
\hline 8 & 6500 & 6800 & 24 & $5.304 \times 10^{8}$ & $6.5 \times 10^{5}$ & 816 & $6.5 \times 10^{6}$ & 82 & $5.2 \times 10^{7}$ & 10.2 \\
\hline 7 & 3000 & 5800 & 10 & $8.700 \times 10^{7}$ & $3 \times 10^{5}$ & 290 & $3 \times 10^{6}$ & 29 & $2.4 \times 10^{7}$ & 3.6 \\
\hline \multicolumn{5}{|c|}{ Total duration (a) } & \multicolumn{2}{|c|}{3486} & \multicolumn{2}{|c|}{349} & \multicolumn{2}{|c|}{43.6} \\
\hline
\end{tabular}

not clearly composed of bedrock (e.g. crag and tails) (Fig. 2). As such, the MSGLs discussed here are likely to comprise a continuum of linear bedforms, including features on the outer shelf that fit the classical description of MSGLs (Clark, 1993) and features on the middle and inner shelf that have more drumlinoid shapes and may be related to underlying bedrock, albeit not exposed at the surface (c.f. Ó Cofaigh and others, 2002; Graham and others, 2009). By grouping these bedforms as MSGLs we avoid the difficulty of attempting to distinguish between features that are likely to evolve from one type to another and without any obvious difference in morphometry. For the classification of all other mapped bedforms, the reader is referred to Livingstone and others (2013).

Using the dataset of mapped MSGLs (Fig. 2), we measured MSGL length, density, height and spacing. Length is measured along the crest line of each mapped MSGL. To investigate the downstream variation in MSGL length, values were assigned to the nearest $1 \mathrm{~km}$ interval along a central flow line (Jamieson and others, 2016) and the mode, median, maximum, minimum and standard deviation (SD) were calculated.

Lineation (line) density was calculated $\left(\mathrm{m} \mathrm{km}^{-2}\right)$ by summing the length of the portion of each MSGL that falls within the $1 \mathrm{~km}$ search radius around each cell, and then dividing by the area of that circle. This method was chosen over the number of MSGLs per area because it accounts for the length of the MSGL, rather than just a single location (e.g. mid-point).

The MSGL heights and spacing were derived from crossprofile transects positioned at $1 \mathrm{~km}$ intervals along the length of Marguerite Trough, stretching from the inner shelf to the continental shelf edge (Fig. 1). Measurements were restricted to regions floored by sediment and with $<2 \mathrm{~m}$ of postglacial sediments. MSGL heights were calculated by taking the mean difference between the ridge crest elevation and the minimum elevation of grooves separating the MSGL from its nearest neighbour. This method assumes that MSGLs form a continuous cross-profile waveform, which may be unrealistic, especially, further upstream where non-MSGL topography (e.g. inner shelf channels) probably results in inflated values. We therefore avoid the innermost part of the shelf and restrict our analysis to the outer $\sim 350 \mathrm{~km}$ of the MBIS trough, thereby focusing on the median of all the measured height values along each transect (rather than the mode) in order to minimise the effect of inflated values. The same principles were applied to the calculation of
MSGL spacing, defined as the across-stream ridge-to-ridge distance.

\subsection{Grounding-zone wedge (GZW) geometry and timescales of formation}

GZWs comprise wedges of diamicton characterised by a steep distal sea-floor ramp and shallow backslope, and are typically tens of kilometres long and tens of metres high (Alley and others, 1989; Batchelor and Dowdeswell, 2015). They are thought to form during periods of grounding-zone stability or minor re-advances (Alley and others, 1989). Acoustic data collected through the GZWs were unable to penetrate to a basal reflector. The volumes of GZWs on the outer shelf were therefore estimated using the long profile of the GZW and, assuming a flat base (e.g. Jakobsson and others, 2012; Klages and others, 2014), the mean thickness of the profile and the GZW width (Table 1). However, this may be a simplification because the volume of a given GZW can be partly 'hidden' below a GZW deposited later, further upstream (Bart and Owolana, 2012). The timescale of GZW formation was calculated from their volume and 3-D sediment flux using the equation

Grounding line still stand duration

$$
=\frac{\text { GZW volume }\left(\mathrm{m}^{3}\right)}{\text { sediment flux }\left(\mathrm{m}^{3} \mathrm{a}^{-1}\right)}
$$

Calculated subglacial 2-D sediment fluxes from modelled, palaeo- and contemporary ice streams typically range between 100 and $1000\left(\mathrm{~m}^{3} \mathrm{a}^{-1}\right.$ (m grounding line width) ${ }^{-1}$ ) (e.g. Alley and others, 1989; Dowdeswell and others, 2004a), with fluxes as high as $8000\left(\mathrm{~m}^{3} \mathrm{a}^{-1}\right.$ (m grounding line width) ${ }^{-1}$ ) estimated for the Norwegian Channel ice stream (Nygård and others, 2007). The three values quoted above were taken as end members and multiplied by the GZW widths to derive a range of realistic 3-D sediment flux across the grounding line.

Sediment fluxes were also calculated using the equation (modified from Hooke and Elverhøi, 1996; Bougamont and Tulaczyk, 2003),

$Q s=\left(k M_{\mathrm{d}} S U \mathrm{~s}\right) w$,

where $Q s=$ sediment flux $\left(\mathrm{m}^{3} \mathrm{a}^{-1}\right), k=$ constant to account 


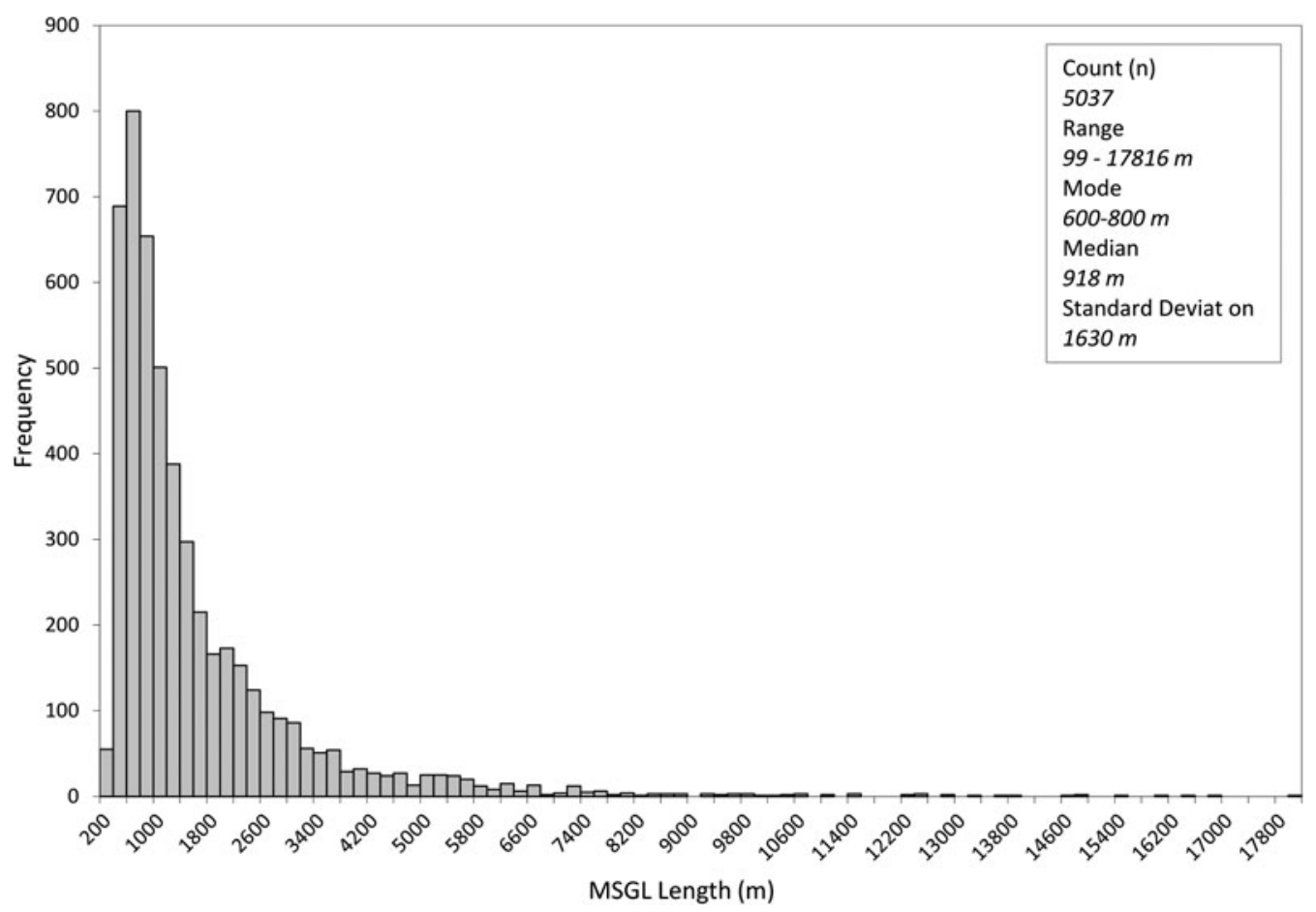

Fig. 3. Frequency histogram of the lengths binned at $200 \mathrm{~m}$ intervals, of the $5037 \mathrm{MSGLs}$ mapped on the palaeo-bed of MBIS. The distribution is heavily skewed to shorter $(<5 \mathrm{~km})$ MSGLs although some outliers reach up to $>17 \mathrm{~km}$ long.

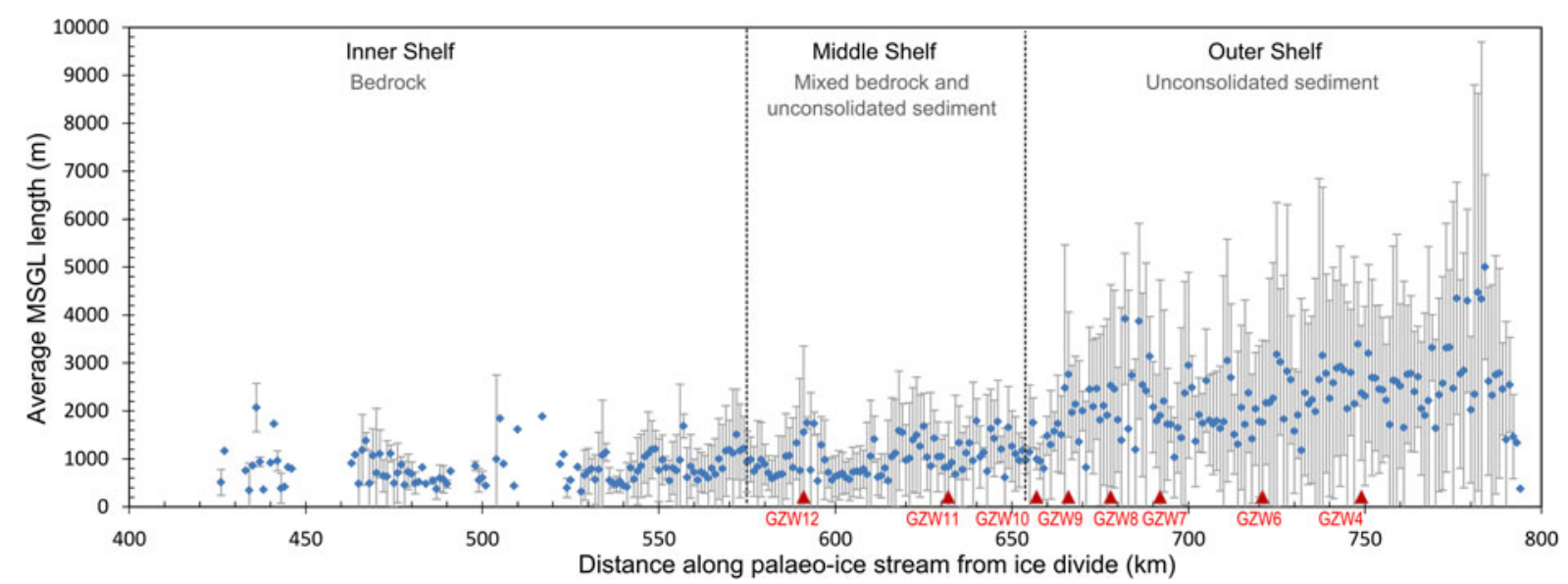

Fig. 4. Mean MSGL length and associated standard deviation calculated at $1 \mathrm{~km}$ intervals from the centre point of each lineation along the length of Marguerite Trough. Red triangles refer to GZW positions within the main trough. The GZWs are numbered as in Figure 2.

for the decrease in deformation with depth, $M_{\mathrm{d}}=$ component of motion attributable to deformation, $S=$ effective thickness of the basal mobile layer $(\mathrm{m}), U_{\mathrm{s}}=$ streaming velocity $\left(\mathrm{m} \mathrm{a}^{-1}\right)$ and $w=$ ice stream width $(\mathrm{m})$.

\section{BASAL CHARACTERISTICS OF MARGUERITE TROUGH PALAEO-ICE STREAM}

\subsection{Morphometry of GZWs}

Livingstone and others (2013) identified 12 GZWs that occur along the length of the middle and outer shelf as localised features in the centre of the trough and on the trough flanks (Fig. 2). They have also been mapped beyond the main trough (GZWs 1-3) near the shelf edge, and are associated with the partial preservation of MSGLs in front of their scarps. Notably, all GZWs are observed in areas with a reverse bed-slope (which drops landward by $\sim 120$ m every
$100 \mathrm{~km}$ on average), and seem to have formed when the rate of MBIS grounding line retreat slowed in areas where the width narrows (Jamieson and others, 2012). Their shape and dimensions are the characteristics of seismically imaged GZWs observed elsewhere in Antarctica and Greenland (e.g. Dowdeswell and Fugelli, 2012; Batchelor and Dowdeswell, 2015).

\subsection{Morphometry of MSGLs}

Analysis of 5037 MSGLs within Marguerite Trough shows their lengths range between $\sim 100$ and $17800 \mathrm{~m}$, with a mode of $600-800 \mathrm{~m}$, median of $918 \mathrm{~m}$ and SD of $1630 \mathrm{~m}$ (Fig. 3). The frequency histogram indicates a unimodal distribution with a skew towards shorter lengths and a long tail of relatively few long MSGLs. The mean and maximum length of MSGLs increases towards the shelf edge (Fig. 4), with the 

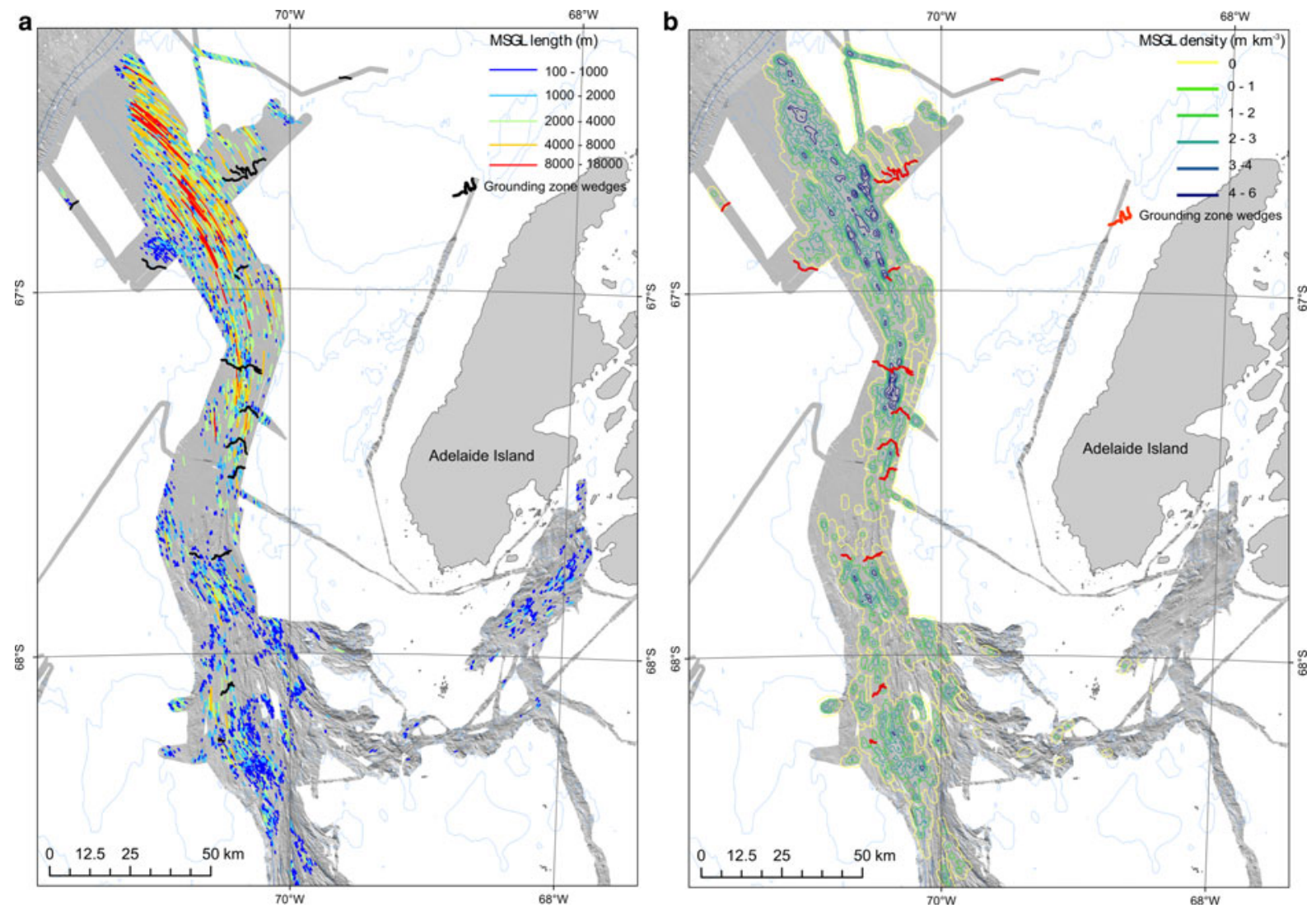

Fig. 5. (a) Map of lineation lengths along Marguerite Trough; and b: lineation density map calculated using a $1 \mathrm{~km}$ radius. GZWs are highlighted in black (a) and red (b).

longest MSGLs concentrated along the central axis of the trough (Fig. 5a). Indeed, the longest (>10 km) MSGLs are clearly observed to cluster together (Fig. 5a; see also Section 4.4).

A noticeable jump in mean length (by $\sim 1 \mathrm{~km}$ ) occurs just downstream of the mid/outer shelf transition (at $\sim 650 \mathrm{~km}$ along the palaeo-ice stream from the ice divide). Subtle increases in MSGL length on the mid-shelf are associated with GZWs 10-12 (Fig. 5a). Superimposed on these general trends is a considerable finer-scale variation, with short ( $<2 \mathrm{~km}$ long) MSGLs ubiquitous along the trough axis and in close proximity to much longer lineations (Figs 4, 5a). The highest MSGL densities occur along the central axis of the trough and on the outer shelf between GZWs 3 and 4 (Fig. 5b). A close correlation between MSGL density and GZW position, with MSGLs tending to cluster on the gentle back-slope of the wedges, is also revealed in Figure 5b.

The median height of all the measured MSGLs along the trough is $7.5 \mathrm{~m}$. However, the median MSGL height of each cross-profile transect within Marguerite Trough ranges from 1 to $30 \mathrm{~m}$, with a clear downward trend with distance from the ice divide (Fig. 6a). On the outer shelf (from 650 $\mathrm{km}$ along MBIS from the ice divide), where MSGLs are much more densely packed, the consistency of heights (median of $\sim 2 \mathrm{~m}$ ) over a distance of over $100 \mathrm{~km}$ is striking. Conversely, on the mid- and inner-shelves, MSGL heights are more variable and can reach $>10 \mathrm{~m}$ in height (Fig. 6a).

The median spacing of all mapped MSGLs along the trough is $335 \mathrm{~m}$. As with the heights, the median MSGL spacing of each cross-profile transect is remarkably consistent across the outer shelf (250-300 m) (Fig. 6b). Although there is not a clear trend with distance from the ice divide, the median spacing becomes much more variable on the mid- and inner-shelves, ranging between 100 and $1500 \mathrm{~m}$.

\subsection{Sediment thickness, flux and deposition}

\subsubsection{Soft till thickness}

The thickness of the soft till becomes increasingly patchy towards the mid- and inner-shelf (Fig. 7). The $\sim 3000 \mathrm{~km}^{2}$ extent of soft till on the outer shelf has a mean thickness of $5.9 \mathrm{~m}$, reaches a maximum of $19 \mathrm{~m}$ and has a total volume of $17.5 \mathrm{~km}^{3}$. However, the layer thickness is variable, with discrete zones of thicker till prevalent towards the centre of the trough (Fig. 7). The spatial distribution and thickness of soft till is consistent with previous results from Dowdeswell and others (2004b) and is similar to thicknesses calculated for the acoustically transparent unit on the bed of palaeoice streams in the NE Antarctic Peninsula (Reinardy and others, 2011b).

\subsubsection{Postglacial sediment thickness}

The spatial distribution and thickness of all postglacial sediments overlying the subglacial till, including deglacial sediments, along the length of Marguerite Trough, gives a volume of $17 \mathrm{~km}^{3}$ (Fig. 8). The inner shelf is characterised by a patchy distribution of postglacial deposits comprising infills of up to $10 \mathrm{~m}$ thickness in topographic lows and $<1 \mathrm{~m}$ thick veneers over bedrock highs (Fig. 8). The western part of the mid-shelf trough is covered by $1-6 \mathrm{~m}$ thick sequences of postglacial sediments (Fig. 8). These deposits occur in close association with GZWs 11-12, with the thickest 

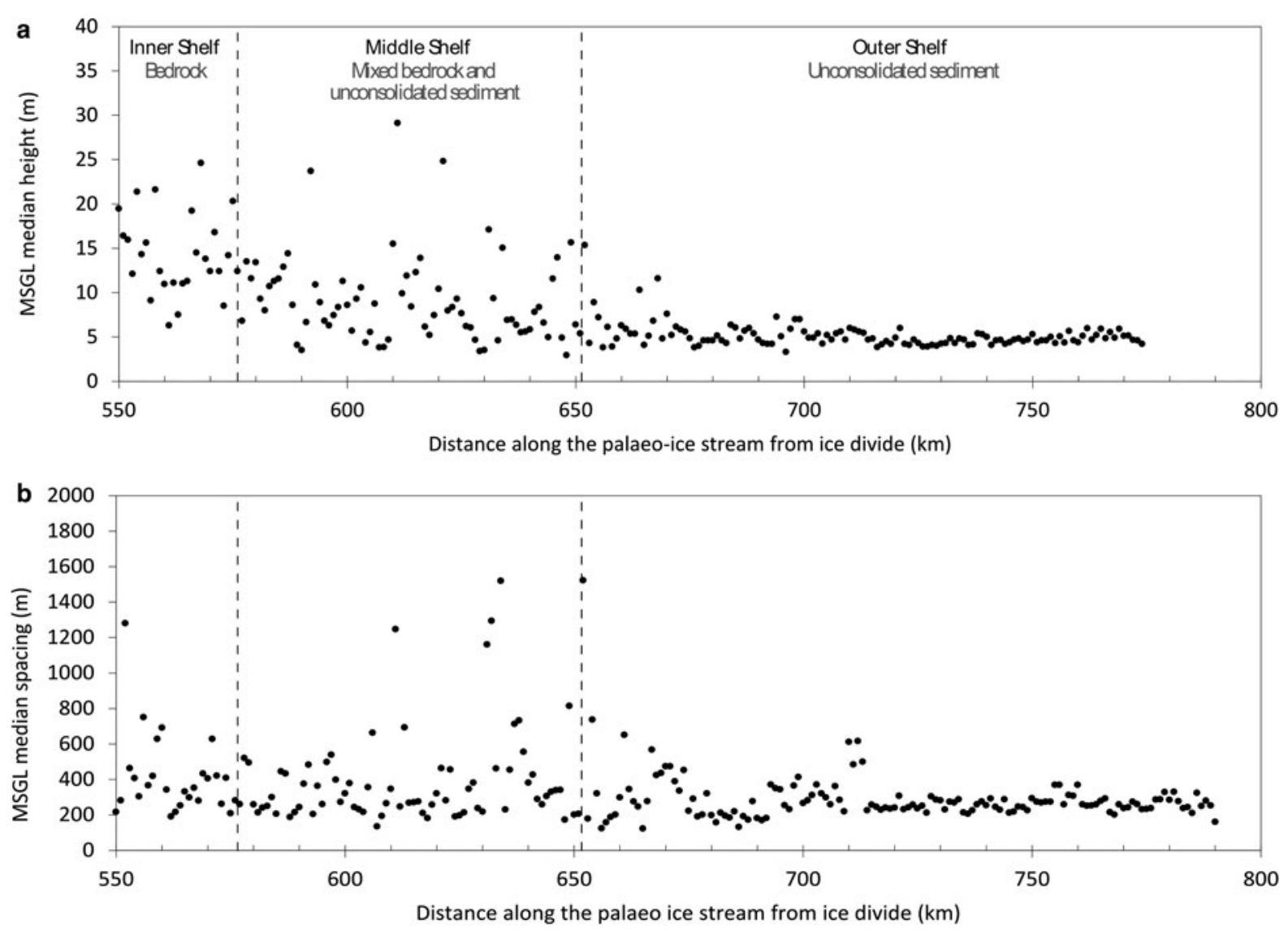

Fig. 6. (a) Scatter graph of median MSGL height plotted against distance along Marguerite Trough. b: Scatter graph of median MSGL lateral spacing plotted against distance along Marguerite Trough. Measurements for (a) and (b) were derived from transects positioned at $1 \mathrm{~km}$ intervals along the length of the ice stream, stretching from the inner shelf (left) to the shelf break (right).

postglacial sediments found in front of major meltwater outlets (Fig. 8) (see also Klages and others, 2014, from the western Amundsen Sea). In general, the postglacial sediment cover is relatively thin on the outer shelf (cf. Ó Cofaigh and others, 2005), although $>2 \mathrm{~m}$ thick postglacial sediment drapes are observed directly offshore from GZWs 6, 7 and 9 (Fig. 8).

\subsection{Relationship between soft till thickness, distance along Marguerite Trough and MSGL length and density}

We observe a significant scatter between MSGL length and density (Fig. 9), although some of the longest lineations $(>8 \mathrm{~km})$ tend to occur in clusters $\left(>2 \mathrm{~m} \mathrm{~km}^{-2}\right)$. Indeed, isolated lineations are typically short $(<5 \mathrm{~km})$ and the lowest densities are associated with the shortest MSGLs (Fig. 9). However, the greatest densities $\left(>5 \mathrm{~m} \mathrm{~km}^{-2}\right)$ are not necessarily associated with the longest lineations (Fig. 9). MSGL length and density clearly increase downstream with distance from the ice divide (Fig. 9a), although there is some variability along the trough (see Fig. 4). Figures $5 \mathrm{a}, 9 \mathrm{~b}$ reveal a close relationship between the length and density of MSGLs and the thickness of soft till. This is further demonstrated by the comparison of soft till thickness with MSGL length (Fig. 10), which shows that the longest MSGLs occur in soft till of intermediate thickness $(\sim 6-12 \mathrm{~m})$ and not in the thickest soft till layers $(>12 \mathrm{~m})$. This trend does not result from the artificial shortening of MSGL lengths by iceberg-keel ploughing on the outer shelf (see Fig. 2). It is in the zone of intermediate soft till thickness, where the densities are also highest (Figs 9 and 10). Furthermore, the longest MSGLs $(>10 \mathrm{~km})$ and densest MSGL concentrations do not form in soft till $<5 \mathrm{~m}$ thick (Fig. 10). Because a basal reflector was not recorded beneath very thick accumulations of soft till, such as under GZWs, this dataset remains incomplete. Nevertheless, although the GZWs probably represent some of the thickest accumulations of soft till, their back-slopes support shorter MSGLs compared with those on the outer-most shelf (Fig. 5a).

\section{DISCUSSION}

\subsection{MSGL formation}

On the mid-shelf, seismic and TOPAS sub-bottom profiler data indicate that bedrock is close to the surface (Kennedy and Anderson, 1989; Bart and Anderson, 1995; Ó Cofaigh and others, 2005; Anderson and Oakes-Fretwell, 2008). Thus, the form (height and width) of MSGLs in this region may have been at least partially influenced by underlying bedrock properties. This is consistent with variable and high relief MSGLs (up to $30 \mathrm{~m}$ high) on the mid-shelf (Fig. 6a). Geologically-controlled MSGLs are likely to be more stable than those composed of soft till as the bedrock relief would have acted as pinning points from which MSGLs were seeded and sustained. We therefore exclude features with clear bedrock control in the following discussion.

The large variability in MSGL length and density, and the prevalence of short MSGLs $(<2 \mathrm{~km})$ along the entire length of the MBIS bed (Figs 4, 5, 9), implies a complex mode 


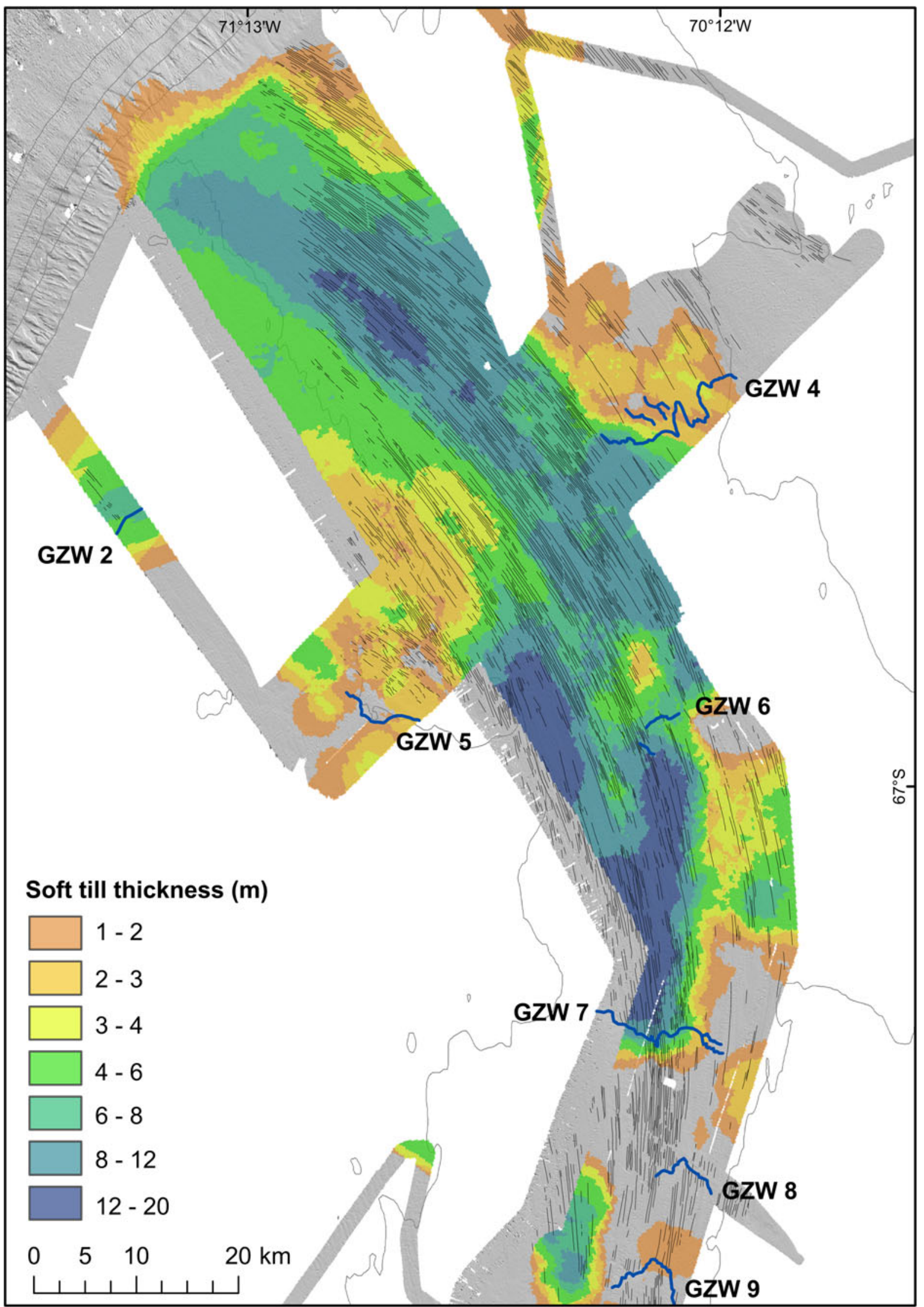

Fig. 7. Soft till thickness map produced from the TOPAS seismic data. Black lines indicate MSGLs and dark blue lines indicate GZWs. Null values (grey) correspond to regions where TOPAS seismic data were not available or where a basal reflector was not observed (e.g. in association with many of the GZWs) and thus soft till may either not be present, or is too thick to measure.

of formation not controlled solely by ice velocity (see also Jamieson and others, 2016). MSGLs are characterised by subtle shifts in orientation along the length of Marguerite
Trough (e.g. upstream and downstream of GZW9: see Fig. 2 inset), which is evidence for a 'smudged' glacial bedform signature. However, these changes in direction do 


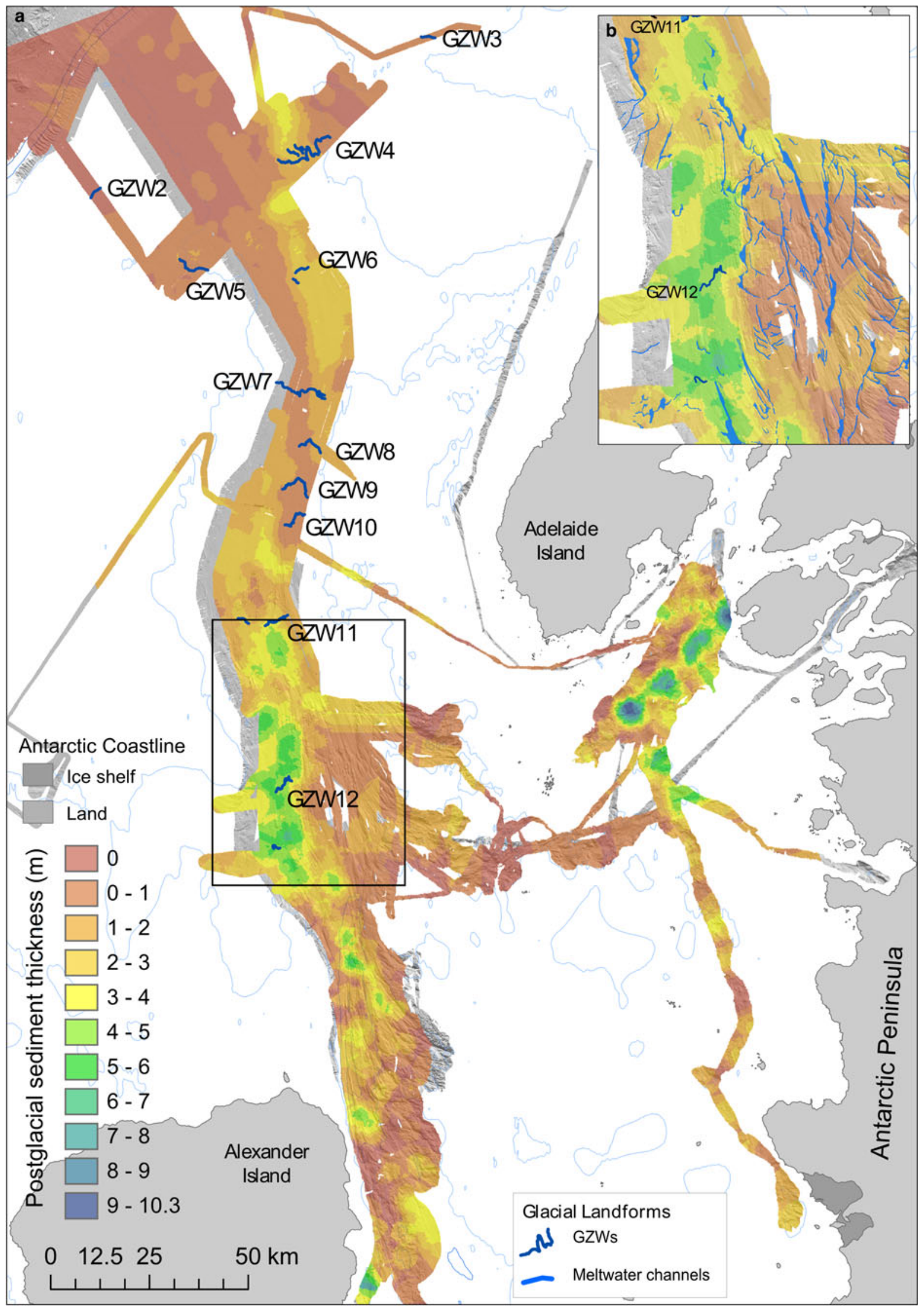

Fig. 8. Thickness of postglacial sediments (including deglacial sediments) produced from the TOPAS seismic data. Inset figure (b) shows the correlation between mapped meltwater channels and postglacial sediments in the vicinity of GZWs 11 and 12 .

not generally manifest themselves as cross-cutting bedforms, which are only occasionally observed on palaeo-ice stream beds (e.g. Evans and others, 2005), but rather as the complete re-organisation of the bedform signature linked to halts or slow-downs in grounding-line retreat, or minor readvances. Large regions of the lineated mid- and outer-shelf are associated with GZW features. Given that MSGLs are formed on top of the GZWs (see Fig. 2), we are confident that features 

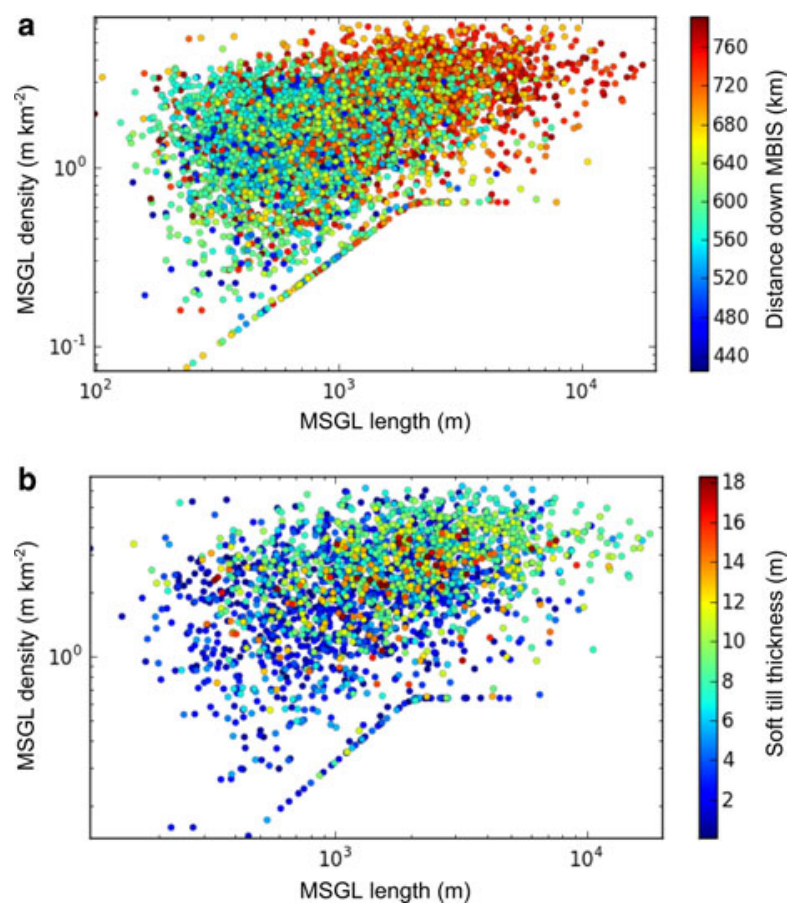

Fig. 9. Log-log scatter plots of MSGL density and length colour coded by: (a) distance from the ice divide downstream Marguerite Trough; and (b) soft till thickness. The sharp limit relates to isolated MSGLs where their density is solely determined by their length. The limit plateaus because isolated lineations $2 \mathrm{~km}$ long and greater have reached the maximum extent of the search diameter $(2 \mathrm{~km})$.

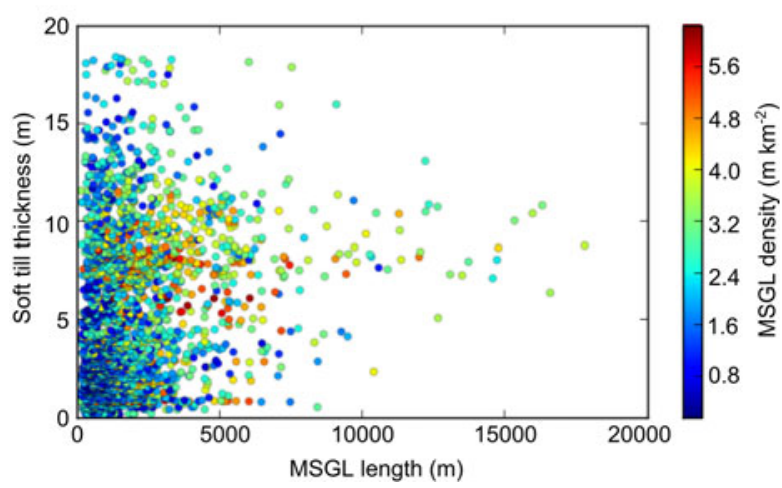

Fig. 10. Scatter plot of soft till thickness and MSGL length, colourcoded by density.

in these particular locations relate to the final deglacial imprint of the ice stream, with older attenuated bedforms having been either destroyed or overprinted (Fig. 2; cf. Graham and others, 2010; Jakobsson and others, 2012). This suggests that overprinting of bedforms occurred at a rate that was able to quickly bury, remould or destroy previous generations of MSGLs formed in soft till and, therefore, that the glacial bedform signature observed in the mid- and outer shelf parts of Marguerite Trough (e.g. the large variability in MSGL length) is not a composite history produced over a long time, i.e. over several thousand to tens of thousands of years. Thus, although MSGLs were constantly generated along the length of the ice stream, the only ones preserved on the sea floor were those formed just (i.e. decades to centuries) prior to deglaciation (e.g. Graham and others, 2009).
This is supported by the data collected beneath Rutford Ice Stream and Pine Island Glacier (West Antarctica), which show the development of subglacial bedforms over subdecadal timescales and high rates of subglacial erosion (Smith and others, 2007, 2012; King and others, 2009).

We suggest that the variability in MSGL length and density along Marguerite Trough reflects glacial bedforms at different stages of maturity (cf. Stokes and others, 2013), consistent with a constantly evolving ice stream bed (cf. King and others, 2009; Reinardy and others, 2011a). The large number (Fig. 3) and widespread occurrence of short MSGLs (Fig. 5) is interpreted to record immature bedforms preserved in the early stages of formation and probably formed just before ice retreated from the area. MSGLs longer than $8 \mathrm{~km}$ are predominantly associated with a particular thickness range of soft till (6-12 m), only occur on the outermost shelf, and form in clusters (Figs 9 and 10). MSGL length (a potential proxy for growth rate) increases downstream in areas of soft till (Fig. 4). Thus, the highest MSGL densities (bedform generation) and longest MSGLs (bedform elongation) preferentially form in regions underlain by thick, soft till rather than thin soft till or stiff till and are presumably associated with zones where deformation was greatest, i.e. along the central axis of the trough on the outer shelf. This conclusion is supported by TOPAS data revealing a predominantly smooth sub-bottom reflector corresponding to the top of the stiff till, which is therefore not thought to have been involved in MSGL formation (Dowdeswell and others, 2004a; Ó Cofaigh and others, 2005, 2007). Similarly, prominent MSGLs are absent in palaeo-ice stream troughs where local outcrops of stiff till are observed, for example in Robertson Trough, eastern Antarctic Peninsula (Evans and others, 2005; Reinardy and others, 2011b). This is consistent with modelling results, which suggest that MSGL length is linked to the speed of the overlying ice and basal conditions such as shear stress (Jamieson and others, 2016).

The main theories to explain the formation of MSGLs in soft sediment include: (1) subglacial deformation of till (Hindmarsh, 1998); (2) groove-ploughing by keels in the basal ice (Clark and others, 2003); (3) meltwater megafloods (Shaw and others, 2008); and (4) a subglacial rilling instability in the hydraulic system (Fowler, 2010). None of these theories are, as yet, widely accepted. However, in relation to the MBIS, the consistent spacing and height of MSGLs over a distance of $>100 \mathrm{~km}$ on the outer shelf of Marguerite Trough (Fig. 6) suggests that MSGLs could represent some form of self-organizing phenomenon (Fowler, 2010; Spagnolo and others, 2014). This implies that their spatial arrangement and height are relatively insensitive to local factors (Spagnolo and others, 2014; Jamieson and others, 2016) and might be dictated by an instability process (e.g. Clark, 2010; Fowler and Chapwanya, 2014 for drumlins). Certainly a similar regularity of arrangement and frequency of spacing has been recorded on other palaeo-ice stream beds (Spagnolo and others, 2014), and this may imply some common mechanism of formation (e.g. Clark, 2010; Fowler and Chapwanya, 2014 for drumlins).

\subsection{Sediment fluxes and formation of GZWs}

\subsubsection{Soft till}

The thickness distribution of soft till (Fig. 7) suggests spatial variability in the magnitude and rate of erosion, transport and deposition of subglacial sediment. For example, linear 

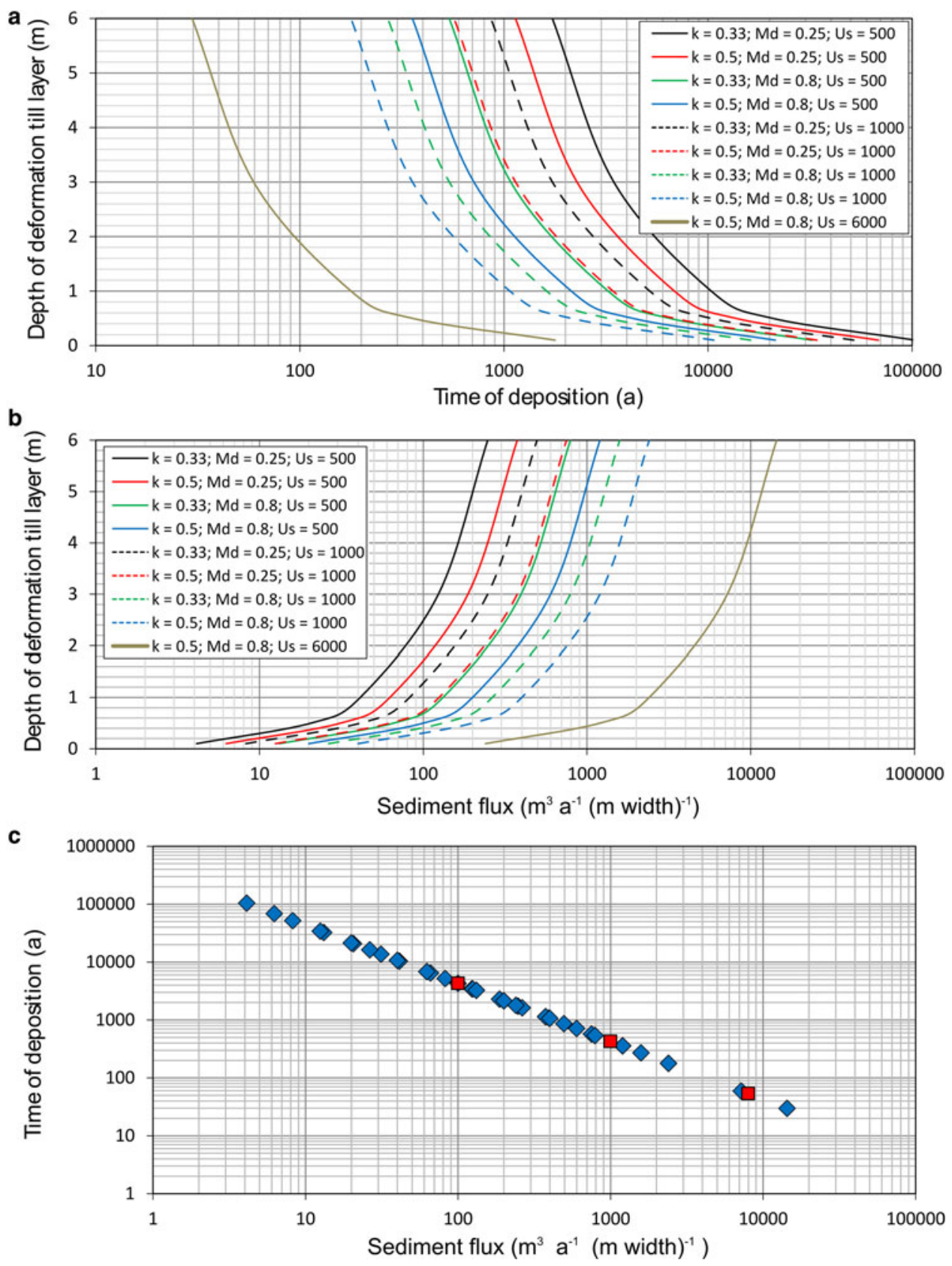

Fig. 11. Sediment fluxes and timescales of GZW deposition calculated as a function of ice stream velocity and the depth of a deforming till layer (Eqns (1) and (2)). (a) Depth of deformation vs time of deposition for a range of realistic values based on observations; (b) depth of deformation vs sediment flux for a range of reasonable values (see Section 3.3); and (c) time of deposition vs sediment flux for the range of values used in ( $a$ and $b)$. The red squares are end-member sediment fluxes $\left(100,1000,8000 \mathrm{~m}^{3} \mathrm{a}^{-1} \mathrm{~m}^{-1}\right.$ ) derived from the literature.

zones of thick, soft till (and also localised GZW formation: Section 5.2.2), which tend to occur along the central axis of the trough, point to a macro-scale level of organisation indicative of focused sediment delivery along discrete flow corridors. Significantly, these linear zones of thick soft till are associated with the densest clusters of, and the longest, MSGLs; indicating preferential growth of subglacial bedforms in these zones (see Section 5.1). This is similar to observations from the bed beneath Rutford Ice Stream, where MSGLs have formed in the soft, dilatant till rather than in zones of stiffer till (King and others, 2009).

\subsubsection{Mechanisms and durations of GZW formation}

Radiocarbon ages on sediment cores suggest that the grounded ice stream stepped back $\sim 140 \mathrm{~km}$ from the outer shelf to the mid shelf at $\sim 14$ cal. ka BP (Figs 1 and 2). This retreat occurred within the error-margin of the dates. Hence, GZWs 7-10 that are located in this zone must have been deposited relatively rapidly (i.e. within a few centuries) with correspondingly high sediment fluxes if they were formed in their entirety during this period. Given the combined volume of $3.42 \mathrm{~km}^{3}$ for GZWs 7-10 and typical 2-D sediment fluxes of $100-1000\left(\mathrm{~m}^{3} \mathrm{a}^{-1}\right.$ (m grounding line width $)^{-1}$ ), the deposition of the GZWs would have taken between 350 and 3500 years (Table 1). If the sediment flux was higher (e.g. $8000\left(\mathrm{~m}^{3} \mathrm{a}^{-1}\right.$ (m grounding line width) $\left.{ }^{-1}\right)$ : cf. Nygård and others, 2007), the four GZWs could have formed in just 44 a (Table 1). Thus, sediment fluxes must have been over $1000\left(\mathrm{~m}^{3} \mathrm{a}^{-1}\right.$ ( $\mathrm{m}$ grounding line width) ${ }^{-1}$ ) for the GZWs to form within the error range of the radiocarbon dates (Fig. 1). This is consistent with flux rates and 
timescales of GZW formation calculated for Pine Island Trough in the eastern Amundsen Sea embayment (Graham and others, 2010; Jakobsson and others, 2012). Indeed, there is a growing body of palaeo-evidence for relatively rapid (centennial-scale) GZW deposition and hence for high sediment fluxes (e.g. Dowdeswell and Fugelli, 2012), although formation of some very large GZWs may have taken up to 25000 a (e.g. Bart and Owolana, 2012). High sediment fluxes are consistent with geophysical observations of modern ice stream beds that indicate high rates of sediment erosion (Smith and others, 2012) and rapid deposition of subglacial landforms (Smith and others, 2007).

Possible fluxes for Eqn (2), given a range of realistic values based on observations for the variables $k, M_{\mathrm{d}}, S$ and $U s$, are shown in Fig. 11. Significantly, the time over which a GZW can be deposited is nonlinearly related to the mobile till layer thickness $(S)$ such that, for $S$ values $<1 \mathrm{~m}$, the timing of deposition becomes unrealistically long $\left(10^{3}-10^{5}\right.$ a) given the chronological constraints of the MBIS, and other ice stream retreat patterns (Fig. 11). Thus, assuming that the deposition of the GZWs occurred in $<1000 \mathrm{a}$, then either $S$ values of $>1 \mathrm{~m}$ or very high ice-flow speeds (upwards of $6000 \mathrm{~m} \mathrm{a}^{-1}$ ), significantly above that modelled for this ice stream (Jamieson and others, 2012, 2014, 2016), are required for the formation of the GZWs solely by advection of deformation till (Fig. 11). This is significant, because till is considered to behave plastically, with deformation concentrated along shallow shear planes (e.g. Tulaczyk and others, 2000a, b; Kavanaugh and Clarke, 2006). This would limit $S$ to values $<1 \mathrm{~m}$ and provide relatively small sediment fluxes, thereby precluding the rapid formation of GZWs by till advection to the grounding line (e.g. Alley and others, 1987). In order to reconcile these observations it might be necessary to invoke additional sediment transport by water or basal freeze-on (e.g. Christoffersen and others, 2010), or that GZWs may have been partially or wholly reworked from pre-existing sediment accumulations.

The paucity of mapped GZWs on the inner- and mid-shelf of Marguerite Trough, where retreat was much slower (Fig. 1), is probably a direct consequence of 'till starvation' as the ice stream retreated onto the hard bedrock, which is more resistant to subglacial erosion than the sedimentary substrate on the outer shelf, and because of reduced sediment supply from upstream. This control on subglacial sediment supply is likely to be accentuated by the availability of sediment along Antarctic palaeo-ice streams, with soft till overlying sedimentary strata on the outer shelf grading into hard bedrock on the inner shelf (Wellner and others, 2001, 2006; Livingstone and others, 2012).

\section{CONCLUSIONS}

We analysed the spatial pattern and morphometry of $>17000$ glacial landforms along the bed of the MBIS Trough, western Antarctic Peninsula (Fig. 2). This has resulted in the following conclusions:

The glacial bedform imprint reflects a time-transgressive signature, whereby MSGLs formed in soft till on the mid- and outer-shelf were being constantly generated, remoulded and destroyed and/or buried along the length of the ice stream, whereas features carved into bedrock on the inner shelf were probably formed over multiple glacial cycles.
The only MSGLs preserved are those that formed just prior to the last deglaciation (cf. Graham and others, 2009).

The variability in MSGL length and density observed along the length of the MBIS bed is indicative of a constantly evolving bed reflecting bedforms at different stages of maturity. The large number and widespread occurrence of short MSGLs $(<2 \mathrm{~km})$ nestled among longer lineations $(>10 \mathrm{~km})$ probably reflects immature bedforms at an early stage of development.

Longer MSGLs cluster together towards the continental shelf edge along the central axis of the trough and are associated with zones of intermediate thickness (6-12 m) of soft till. Lineation growth and formation is therefore associated with regions where deformation was presumably the greatest.

The consistent spacing (250-300 m) and height ( $2 \mathrm{~m})$ of MSGLs on the outer shelf of Marguerite Trough supports the idea that MSGLs represent a self-organizing phenomenon and thus their spatial arrangement and height might be dictated by an instability process (e.g. Clark, 2010; Fowler and Chapwanya, 2014). Variations in MSGL height and spacing on the middle shelf likely reflect an underlying geological control.

Linear zones of thick soft till and localised GZW formation imply focused sediment delivery along discrete flow corridors within the MBIS. This finding indicates spatial variability in the rate and magnitude of erosion, transport and deposition of subglacial till as well as the processes of deformation and lodgement.

The GZWs on the outer shelf of Marguerite Trough are likely to have formed within $\sim 1000 \mathrm{a}$. Therefore, the till fluxes were probably up to $1000\left(\mathrm{~m}^{3} \mathrm{a}^{-1}\right.$ (m grounding line width) ${ }^{-1}$ ) (assuming no additional processes of sediment supply, such as basal freeze-on or subglacial meltwater flow). Soft till advection is primarily controlled by the depth of the mobile till layer, which must have been $>1$ $\mathrm{m}$ thick, or associated with rapid basal sliding velocities (upwards of $6 \mathrm{~km} \mathrm{a}^{-1}$ ) to produce the necessary sediment volumes to form the GZWs.

\section{ACKNOWLEDGEMENTS}

This work was funded by Natural Environmental Research Council (NERC) UK standard grants NE/G015430/1 and NE/G018677/1. Jamieson was supported by NERC Fellowship NE/J018333/1 and Spagnolo was supported by NERC new investigator grant NE/J004766/1. Underlying data are available by request to Livingstone. This research would not have been possible without the hard work of scientists and crew during research cruises JR59, JR71, JR157 and NBP0201. We thank two anonymous reviewers for their comments, which helped to improve the manuscript. We also thank Jeremy Ely for his comments on an earlier draft.

\section{REFERENCES}

Alley RB, Blankenship DD, Bentley CR and Rooney ST (1986) Deformation of till beneath ice stream B, West Antarctica. Nature, 332, 57-59 (doi: 10.1038/322057a0)

Alley RB, Blankenship DD, Bentley CR and Rooney ST (1987) Till beneath Ice Stream B 3. Till deformation: evidence and implications. J. Geophys. Res., 92, 8921-8929 
Alley RB, Blankenship DD, Rooney ST and Bentley CR (1989) Sedimentation beneath ice shelves - the view from Ice Stream B. Mar. Geol., 85, 101-120 (doi: 10.1016/0025-3227(89)90150-3)

Anandakrishnan S, Blankenship DD, Alley RB and Stoffa PL (1998) Influence of subglacial geology on the position of a West Antarctic ice stream from seismic observations. Nature, 394, 62-65 (doi: 10.1038/27889)

Anderson JB (1999) Antarctic Marine Geology. Cambridge University Press, Cambridge

Anderson JB and Oakes-Fretwell L (2008) Geomorphology of the onset area of a palaeo-ice stream, Marguerite Bay, Antarctica Peninsula. Earth Surf. Process. Landf., 33, 503-512 (doi: 10.1002/esp.1662)

Bamber JL, Vaughan DG and Joughin I (2000) Widespread complex flow in the interior of the Antarctic Ice Sheet. Science, 287, 1248-1250 (doi: 10.1126/science.287.5456.1248)

Bart P and Owolana B (2012) On the duration of West Antarctic Ice Sheet grounding events in Ross Rea during the Quaternary. Quat. Sci. Rev., 47, 101-115 (doi: 10.1016/j.quascirev.2012.04.023)

Bart PJ and Anderson JB (1995) Seismic record of glacial events affecting the Pacific margin of the northwestern Antarctic Peninsula. Am. Geophys. Union, Antarct. Res. Ser., 68, 74-95

Batchelor CL and Dowdeswell JA (2015) Ice-sheet grounding-zone wedges (GZWs) on high-latitude continental margins. Mar. Geol., 363, 65-92 (doi: 10.1016/j.margeo.2015.02.001)

Bougamont M and Tulaczyk S (2003) Glacial erosion beneath ice streams and ice-stream tributaries: constraints on temporal and spatial distribution of erosion from numerical simulations of a West Antarctic ice stream. Boreas, 32, 178-190 (doi: 10.1111/ j.1502-3885.2003.tb01436.x)

Caress DW and Chayes DN (2003) MB-System Version 5. See the website http://www.Ideo.columbia.edu/pi/MB-System Open source software distributed from the MBARI and LDEO web sites

Christoffersen PS, Tulaczyk SM and Behar S (2010) Basal ice sequences in Antarctic ice streams: exposure of past hydrological conditions and a principle mode of sediment transfer. J. Geophys. Res., 115, F03034 (doi: 10.1029/2009JF001430)

Clark CD (1993) Mega-scale glacial lineations and cross-cutting iceflow landforms. Earth Surf. Process. Landf., 18, 1-29 (doi: 10.1002/esp.3290180102)

Clark CD (2010) Emergent drumlins and their clones: from till dilatancy to flow instabilities. J. Glaciol., 51, 2011-1025 (doi: 10.3189/002214311796406068)

Clark CD, Tulaczyk SM, Stokes CR and Canals M (2003) A grooveploughing mechanism for the production of mega-scale glacial lineations, and implications for ice stream mechanics. J. Glaciol., 49, 240-256 (doi: 10.3189/172756503781830719)

Dowdeswell JA and Fugelli EMG (2012) The seismic architecture and geometry of grounding zone wedges formed at the marine margins of past ice sheets. Geol. Soc. Am. Bull., 124, 17501761 (doi: 10.1130/B30628.1)

Dowdeswell JA, Cofaigh CÓ and Pudsey CJ (2004a) Thickness and extent of the subglacial till layer beneath an Antarctic palaeo-ice stream. Geology, 32, 13-16 (doi: 10.1130/G19864.1)

Dowdeswell JA, Cofaigh CÓ and Pudsey CJ (2004b) Continental slope morphology and sedimentary processes at the mouth of an Antarctic palaeo ice stream. Mar. Geol., 204, 203-214 (doi: 10.1016/S0025-3227(03)00338-4)

Engelhardt $\mathrm{H}$ and Kamb B (1997) Basal hydraulic system of a West Antarctic ice stream: constraints from borehole observations. J. Glaciol., 43, 207-230

Evans J, Pudsey CJ, Cofaigh CÓ, Morris PW and Domack EW (2005) Late Quaternary glacial history, dynamics and sedimentation of the eastern margin of the Antarctic Peninsula Ice Sheet. Quat. Sci. Rev., 24, 741-774 (doi: 10.1016/j.quascirev.2004.10.007)

Fowler AC (2010) The formation of subglacial streams and megascale glacial lineations. Proc. R. Soc. A: Math. Phys. Eng. Sci., 466, 3181-3201 (doi: 10.1098/rspa.2010.0009)

Fowler AC and Chapwanya M (2014) An instability theory for the formation of ribbed moraine, drumlins and mega-scale glacial lineations. Proc. R. Soc. Lond. A, 470, 20140185 (doi: 10.1098/rspa.2014.0185)

Graham AGC and 5 others (2009) Bedform signature of a West Antarctic ice stream reveals a multi-temporal record of flow and substrate control. Quat. Sci. Rev., 28, 2774-2793 (doi: 10.1016/j.quascirev.2009.07.003)

Graham AGC and 8 others (2010) Flow and retreat of the Late Quaternary Pine Island-Thwaites palaeo-ice stream, West Antarctica. J. Geophys. Res., 115, F03025 (doi: 10.1029/ 2009JF001482)

Harden SL, DeMaster DJ and Nittrouer CA (1992) Developing sediment geochronologies for high-latitude continental shelf deposits: a radiochemical approach. Mar. Geol., 103, 69-97

Heroy DC and Anderson JB (2005) Ice-sheet extent of the Antarctic Peninsula region during the Last Glacial Maximum (LGM) insights from glacial geomorphology. GSA Bull., 117, 14971512 (doi: 10.1130/B25694.1)

Heroy DC and Anderson JB (2007) Radiocarbon constraints on Antarctic Peninsula Ice Sheet retreat following the Last Glacial Maximum (LGM). Quat. Sci. Rev., 26, 3286-3297 (doi: 10.1016/j.quascirev.2007.07.012)

Hindmarsh RCA (1998) Drumlinisation and drumlin-forming instabilities: viscous till mechanisms. J. Glaciol., 44, 293-314

Hooke RL and Elverhøi A (1996) Sediment flux from a fjord during glacial periods, Isfjorden, Spitsbergen. Glob. Planet. Change, 12, 237-249

Jakobsson $\mathrm{M}$ and 8 others (2012) Ice sheet retreat dynamics inferred from glacial morphology of the central Pine Island Bay Trough, West Antarctica. Quat. Sci. Rev., 38, 1-10 (doi: 10.1016/j. quascirev.2011.12.017)

Jamieson SS, Vieli A, Ó Cofaigh C, Stokes CR, Livingstone SJ and Hillenbrand CD (2014) Understanding controls on rapid icestream retreat during the last deglaciation of Marguerite Bay, Antarctica, using a numerical model. J. Geophys. Res., 119, 247-263 (doi: 10.1002/2013JF002934)

Jamieson SSR and 6 others (2012) Ice stream grounding-line stability on a reverse bed slope. Nat. Geosci., 5, 799-802 (doi: 10.1038/ NGEO1600)

Jamieson SSR and 6 others (2016) Subglacial processes on an Antarctic ice stream bed: 2. Comparison between modelled ice dynamics and subglacial bedform imprint. J. Glaciol.

Kavanaugh JL and Clarke GKC (2006) Discrimination of the flow law for subglacial sediment using in situ measurements and an interpretation model. J. Geophys. Res., 111, F01002 (doi: 10.1029/ 2005JF000346)

Kennedy DS and Anderson JB (1989) Glacial-marine sedimentation and Quaternary glacial history of Marguerite Bay, Antarctic Peninsula. Quat. Res., 31, 255-276 (doi: 10.1016/0033-5894 (89)90008-2)

Kilfeather AA and 5 others (2011) Ice stream retreat and ice shelf history in Marguerite Bay, Antarctic Peninsula: sedimentological and formainiferal signatures. Geol. Soc. Am. Bull., 123, 9971015 (doi: 10.1130/B30282.1)

King EC, Hindmarsh RCA and Stokes CR (2009) Formation of megascale glacial lineations observed beneath a West Antarctic ice stream. Nat. Geosci., 2, 585-588 (doi: 10.1038/ngeo581)

Klages JP and 7 others (2014) Retreat of the West Antarctic Ice Sheet from the western Amundsen Sea shelf at a pre- or early LGM stage. Quat. Sci. Rev., 91, 1-15 (doi: 10.1016/j.quascirev.2014. 02.017)

Klages JP and 7 others (2015) Palaeo-ice stream pathways and retreat style in the easternmost Amundsen Sea Embayment, West Antarctica, revealed by combined multibeam bathymetric and seismic data. Geomorphology, 245, 207-222 (doi: 10.1016/j. geomorph.2015.05.020)

Larter RD, Rebesco M, Vanneste LE, Gamboa LAP and Barker PF (1997) Cenozoic tectonic, sedimentary and glacial history of the continental shelf west of Graham Land. Am. Geophys. Union, Antarct. Res. Ser., 71, 1-27 
Livingstone SJ and 5 others (2012) Antarctic palaeo-ice streams. EarthSci. Rev., 111, 90-128 (doi: 10.1016/j.earscirev.2011.10.003)

Livingstone SJ and 5 others (2013) Glacial geomorphology of Marguerite Bay Palaeo-Ice Stream, western Antarctica Peninsula. J. Maps, 9, 558-572 (doi: 10.1080/17445647.2013.829411)

Moon T, Joughin I, Smith B and Howat I (2012) 21 st Century evolution of Greenland outlet glacier velocities. Science, 336, 576578 (doi: 10.1126/science.1219985)

Nygård A and 5 others (2007) Extreme sediment and ice discharge from marine-based ice streams: new evidence from the North Sea. Geology, 35, 395-398 (doi: 10.1130/G23364A.1)

Ó Cofaigh C, Pudsey CJ, Dowdeswell JA and Morris P (2002) Evolution of subglacial bedforms along a paleo-ice stream, Antarctic Peninsula continental shelf. Geophys. Res. Lett., 29, 41-1-41-4 (doi: 10.1029/2001.GL014488)

Ó Cofaigh C and 6 others (2005) Flow dynamics and till genesis associated with a marine-based Antarctic palaeo-ice stream. Quat. Sci. Rev., 24, 709-740 (doi: 10.1016/j.quascirev.2004.10.006)

Ó Cofaigh C, Evans J, Dowdeswell JA and Larter RD (2007) Till characteristics, genesis and transport beneath Antarctic palaeo-ice streams. J. Geophys. Res., 112, F03006 (doi: 10.1029/ 2006JF000606)

Ó Cofaigh C, Dowdeswell JA, Evans J and Larter RD (2008) Geological constraints on Antarctic palaeo-ice-stream retreat. Earth Surf. Process. Landf., 33, 513-525 (doi: 10.1002/ esp.1669)

Ó Cofaigh C and 17 others (2014) Reconstruction of ice-sheet changes in the Antarctic Peninsula since the Last Glacial Maximum. Quat. Sci. Rev., 100, 87-110 (doi: 10.1016/j. quascirev.2014.06.023)

Parizek BR, Alley RB, Anandakrishnan S and Conway H (2002) Subcatchment melt and long-term stability of Ice Stream D, West Antarctica. Geophys. Res. Lett., 29, 1214 (doi: 10.1029/ 2001GL014326)

Pope PG and Anderson JB (1992) Late Quaternary glacial history of the northern Antarctic Peninsula's western continental shelf: evidence from the marine record. Antarct. Res. Ser., 57, 63-91

Pritchard HD, Arthern RJ, Vaughan DG and Edwards LA (2009) Extensive dynamic thinning on the margins of the Greenland and Antarctic ice sheets. Nature, 461, 971-975 (doi: 10.1038/ nature08471)

Reinardy BTI, Hiemstra J, Murray T, Hillenbrand CD and Larter R (2011a) Till genesis at the bed of an Antarctic Peninsula palaeo-ice stream as indicated by micromorphological analysis. Boreas, 40, 498-517 (doi: 10.1111/j.1502-3885.2010.00199.x)
Reinardy BTI and 5 others (2011b) Streaming flow of an Antarctic Peninsula palaeo-ice stream, both by basal sliding and deformation of substrate. J. Glaciol., 57, 596-608 (doi: 10.3189/ 002214311797409758)

Schoof C (2002) Basal perturbations under ice streams: form drag and surface expression. J. Glaciol., 48, 407-416 (doi: 10.3189/ 172756502781831269)

Shaw J, Pugin A and Young R (2008) A meltwater origin for Antarctic shelf bedforms with special attention to megalineations. Geomorphology, 102, 364-375 (doi: 10.1016/j.geomorph. 2008.04.005)

Smith AM and 6 others (2007) Rapid erosion, drumlin formation, and changing hydrology beneath an Antarctic ice stream. Geology, 35, 127-130 (doi: 10.1130/G23036A.1)

Smith AM, Bentley CR, Bingham RG and Jordan TA (2012) Rapid subglacial erosion beneath Pine Island Glacier, West Antarctica. Geophys. Res. Lett., 39, L12501 (doi: 10.1029/ 2012GL051651)

Spagnolo M and 7 others (2014) Size, shape and spatial arrangement of mega-scale glacial lineations. Earth Surf. Process. Landf., 39, 1432-1448 (doi: 10.1002/esp.3532)

Stokes CR and Clark CD (2001) Palaeo-ice streams. Quat. Sci. Rev., 20, 1437-1457 (doi: 10.1016/S0277-3791(01)00003-8)

Stokes CR, Clark CD, Lian OB and Tulaczyk S (2007) Ice stream sticky spots: a review of their identification and influence beneath contemporary and palaeo-ice streams. Earth-Sci. Rev., 81, 217-249 (doi: 10.1016/j.earscirev.2007.01.002)

Stokes CR and 5 others (2013) Formation of mega-scale glacial lineations on the Dubawnt Lake Ice Stream bed: 1. Size, shape and spacing from a large remote sensing dataset. Quat. Sci. Rev., 77, 190-209 (doi: 10.1016/j.quascirev.2013.06.003)

Tulaczyk SB, Kamb B and Engelhardt HF (2000a) Basal mechanisms of Ice Stream B, West Antarctica 1: till mechanics. J. Geophys. Res., 105, 463-481

Tulaczyk SB, Kamb B and Engelhardt HF (2000b) Basal mechanisms of Ice Stream B, West Antarctica 2: undrained plastic bed model. J. Geophys. Res., 105, 483-494

Wellner JS, Lowe AL, Shipp SS and Anderson JB (2001) Distribution of glacial geomorphic features on the Antarctic continental shelf and correlation with substrate: implications for ice behaviour. J. Glaciol., 47, 397-411 (doi: 10.3189/ 172756501781832043)

Wellner JS, Heroy DC and Anderson JB (2006) The death mask of the Antarctic ice sheet: comparison of glacial geomorphic features across the continental shield. Geomorphology, 75, 157-171 (doi: 10.1016/j.geomorph.2005.05.015) 